\title{
Antifungal Effects of Senescence Terminalia Cattappa Leaves Extract on Disease Pathogens Associated With the Infestation of Hypsipyla robusta on Khaya grandifoliola
}

\author{
Asuelimen E.G \\ Forestry Research Institute of Nigeria \\ Ikhatua M. I \\ University of Benin \\ Daniel Chukwuemeka Amaogu ( $\sim$ amaogu.daniel.chukwuemeka@gmail.com ) \\ Forestry Research Institute of Nigeria
}

\section{Research Article}

Keywords: Hypsipyla robusta, Infestation, Khaya grandifoliola, Pathogens, Inhibition

Posted Date: June 2nd, 2021

DOI: https://doi.org/10.21203/rs.3.rs-580648/v1

License: (c) (i) This work is licensed under a Creative Commons Attribution 4.0 International License.

Read Full License 


\section{Abstract}

The causal organisms responsible for leaf blight and twig dieback on the saplings of Khaya grandifoliola infested with Hypsipyla robusta were investigated. Isolation of pathogens and subculturing of isolates from infested $K$. grndifoliola tissues were carried out using Potato Dextrose Agar (PDA). The inhibitory effects of $T$. cattapa leaves on the mycelial growth of identified pathogens were carried at different concentration of grounded $T$. cattapa leaves $(0.0 \mathrm{~g} 2 \mathrm{~g}, 4 \mathrm{~g}, 8 \mathrm{~g}$, and $10 \mathrm{~g})$ per litre of standard PDA medium in five replicates using CRD. One way ANOVA was carried out on data obtained from the radial measurements of mycelia growths on each pathogen $(a=0.05)$, and mean separations was done using LSD. Identified isolates from leaf blight were Rhizoctonia $s p$. and Colletotrichum $s p$. The isolates from the twig dieback were Fusarium sp. Fusarium sp radial mycelial varied significantly $(\mathrm{P}<0.05)$ among the control, $4.0 \mathrm{~g} / \mathrm{l}, 6.0 \mathrm{~g} / \mathrm{l}$, while there was no significant difference $(p>0.05)$ between the control and $10.0 \mathrm{~g} / \mathrm{l}$. The highest percentage inhibition for Fusarium sp. was observed on $4.0 \mathrm{~g} / \mathrm{l}$. Also, radial mycelial growth of Rhizoctonia $s p$ varied significantly $(P<0.05)$ between $4.0 \mathrm{~g} / \mathrm{l}$ and other concentration levels while maintaining the highest percentage $(7.17 \%)$ inhibition. Therefore, it was concluded that pathogens responsible for leaf blight and twig dieback of Khaya grandifoliolia trees following the infestation of Hypsipyla robusta were Rhizoctonia sp and Fusarium sp, respectively. The study also revealed that $T$. cattapa senescence leaves liquid extracts has the potency of controlling the pathogens.

\subsection{Background Of The Study}

Khaya grandifoliola is a tree species belonging to the Meliaceae family and popularly known as African mahogany is one of the highly valued tropical tree species globally due to its multipurpose values. (Geographically, it is native to West Africa and can be found growing naturally in Nigeria, Guinea-Bissau, Sudan, Congo, Cote d'Ivoire, Cameroon, Ghana, Uganda, among other tropical regions of the world (Lemmens 2008; Opuni-Frimpong, 2008; Okere \& Adegeye, 2011; Fern, 2014). Upon maturity, the tree species can reach $40 \mathrm{~m}$ and $5 \mathrm{~m}$ growth increments in height and girth, respectively (Oyewale et al., 2016). Its bark is usually pale grey with smooth upper boles cracking near the base forming irregular scales. It is blessed with pinnate leaves up to $50 \mathrm{~cm}$ long with 6-10 leaflets and rounded woody capsules, incasing rebrown winged seeds as fruits.

Internationally, African mahogany timbers are highly-priced and valued due to their desirable features like straight grain, usually free from pockets and voids (Okere \& Adegeye, 2011; Abbiv, 1990 cited in OpuniFrimpong, 2014). The wood from this tree species is water-resistant, colourful and shiny when polished (Lemmens, 2008). These and many other inherent features explain its aged longed applications in furniture making, carpentry, shipbuilding, flooring, carving, interior trims, acoustic instruments etc (Fem, 2014; Opoku et al., 2016).

As a member of the Meliaceae family, African Mahogany produces bioactive compounds that have helped create biopesticides for agricultural production and medicines for the health care industries (Nakatani et al., 2004). Literature (Odugbeni et al., 2007; Olowokudejo et al., 2008) shows that 
concoctions prepared from the tree are employed in folk medicine to treat malaria, convulsion, stomach upsets, rheumatism, skin diseases, cough etc. in Nigeria. The efficacy of concoctions and decoction from the tree species in handling such conditions has prompted numerous researches on the antifungal, antibacterial and even antiviral potency of the bioactive compounds in Khaya grandifoliola.

As there are plethoras of benefits accrued to Khaya gandifoliola, common expectations should be establishing more plantations of the tree species and conserving its natural stands in the tropics where they grow. Regrettably, approaches have met many challenges due to the menace of Hysipyla robusta attacks on the tree species in its tropical range (Hauxwell et al., 2001; Opuni-Frimpong et al., 2005, 2008a). The invasion of $H$. robusta on the tree species creates both economic and silvicultural problems. The former arises from the boring activities of the insect pest on the tree stems, while the latter is a consequence of the insect pest activity on the growing shoots of the young seedlings and saplings. $\mathrm{H}$. robusta stem boring activity destroys the apical regions of the growing tree. This triggers the formation of undesirable branches, knots and holes (Griffiths, 2001; Opuni-Frimpong et al., 2014). The infestation ultimately makes the plant vulnerable to the leaf blight and twig dieback infection; this, in turn, reduces the grade and economic value of the timber (Opuni-Frimpong et al., 2014).

Much research has been dedicated to controlling the H. robusta attacks on Khayagrandifoliola - either through pesticides, biocides, cultural practices, or management practices. In the end, little or no research has been done to identify the bioactive pathogens associated with $H$. robusta attacks and how to halt their catastrophic activities. The need to pursue research understandings on pathogenic activities after $H$. robusta infestations on Khayaspp cannot be overemphasised. Evidence has proven that it is practically impossible to completely eradicate $H$. robusta attacks on plantations or natural stands of Khaya spp (Bosu and Nkrumah, 2011). To further exacerbate the condition of Khaya grandifoliola, its higher demand has threatened it to extinctions as overexploitation have been its fateful date (FAO, 2005; IUCN, 2006)

Owing to these unfortunate realities, it is therefore imperative to look for scientific and eco-friendly ways of saving the populations of these tree species. To achieve this, the containment of the diseases associated with $\mathrm{H}$. robusta infestation on Khaya grandifoliola is of paramount importance. The global inclination towards zero synthetic chemicals for agroforestry and silvicultural practices should call for more attention to identify eco-friendly bio-extracts that can suppress the pathogens.

Therefore, the study investigates the various disease pathogens that infect the host plant species after being rendered susceptible by H.robusta infestations. The seemingly scabby, twisted leaves and resulting dieback on the stem - alongside the perforations on the apical shoots due to the activities of the pest, inspired this research. We seek to identify the active disease pathogens on the tree species and the efficacy of crude leaf extracts of Terminalia catappa to inhibit their mycelial growth.

\subsection{Materials And Methods}

\subsection{Collection of Samples}


The collection of diseased leaves and stem of Khaya grandifoliola was carried out from saplings behind the new building of the Faculty of Agriculture, University of Benin, Ugbowo Campus, Benin City. The samples were taken to the laboratory for pathological studies. Photographs of the samples were also taken.

\subsection{Preparation of Medium \\ 2.2.1 Potato Dextrose Agar (PDA)}

The solid agar medium used for culturing fungi was Potato Dextrose Agar (PDA) ACCUMIX brand. 39g of PDA was added to one litre of water in a calibrated conical flask. The mixture in the conical flask was gently shaken to ensure a uniform dissolution and placed inside an autoclave at $121^{\circ} \mathrm{C}$ for 15 minutes at $15 \mathrm{psi}$ (pounds per square inch) for sterilisation. The medium was allowed to cool down before pouring into plates $\left(9 \mathrm{~cm}\right.$ Petri dishes) previously sterilised inside an oven at $160^{\circ} \mathrm{C}$ for 2 hours.

\subsection{Pouring of medium}

The medium pouring was done in the lamina flow hood, which was previously surfaced sterilised with cotton wool and methylated spirit to ensure a sterile environment. The materials required for pouring were placed in the flow hood, and it was switched on for about 15 minutes to ensure proper air circulation free from atmospheric spores. The conical flask containing the medium was flamed at the mouth using a spirit lamp to keep it free of any contaminant. $15 \mathrm{ml}$ of the medium was poured into the plates and was allowed to cool down for solidification.

\subsection{Isolation}

Tissue samples of Khaya grandifoliola, obtained from the zone between the healthy and the diseased portion of the leaves and stem, were cut into bits of about 2-4mm using a pair of scissors and scalpel. These were surfaced sterilised using a bleach solution $(1 ; 4, \mathrm{~V}: \mathrm{V}$ of bleach to water) in a universal bottle for three minutes and then decanted. The isolation procedure was carried out in the lamina flow hood, cleaned with methylated spirit to ensure surface sterilisation. The sterile samples were removed from the universal bottle and were placed on a sterile tissue paper to ensure that they were drained from bleach solution with the aid of sterile forceps. Using the sterile forceps, the tissue samples were inoculated into each plate of the PDA medium in the Petri dishes. The inoculated plates were sealed with cling film to protect them from contaminant and kept at a room temperature of $30 \pm 2^{\circ} \mathrm{C}$. Daily observation of the plates was made to keep pace with the microbial growth, and records were kept.

\subsection{Subculturing}

This procedure was carried out to obtain pure cultures of the isolates. Using an inoculating needle, the inoculums (hyphae) of the isolates were introduced into a sterile plate containing the PDA medium within the lamina flow hood. The plates were labelled and sealed with a cling film and incubated at a room temperature of $30 \pm 2^{\circ} \mathrm{C}$. Photographs of pure cultures were taken on the seventh day.

\subsection{Identification of Isolates}


Slides of individual isolates were prepared. Preparation of slides was done using a sterile needle to transfer hyphae from the pure cultures of isolates to the drop of water on a clean glass slide. The hyphae were teased with the aid of the inoculating needles and covered with coverslips. For isolates with hyaline hyphae, cotton blue-in-lactophenol was used as a mountant. The slides were viewed under a light microscope to identify the isolates based on their morphological characteristics of vegetative hyphae and spores (Barnette and Hunter 1998).

\subsection{Pathogenicity Test}

Twenty vigorous and healthy seedlings of khaya grandifoliola were procured, and their leaves were surfaced sterilised with sterile water. The isolates of 8-day old cultures were teased with sterile water in the glass plate and were inoculated unto the leaves via brushing. Each isolate was inoculated on the stems of the five seedlings with a sterile inoculating needle through boring holes into the stem. Another five seedlings were kept aside as a control. Control seedlings were not inoculated. The control and inoculated seedlings were kept under humid transparent polythene bags for 48hours, after which they were removed and placed under a tent made with nets to prevent insect attack. Observations were made daily for 2 weeks after injections, and records were kept.

\subsection{Preparation of PDA Medium amended with Terminaliacatappa}

The senescence leaves of Terminalia catappa were obtained, and oven-dried at $60^{\circ} \mathrm{C}$ for 72 hours and was milled into powdery form. $39 \mathrm{~g}$ of PDA was weighed and dissolved in $1000 \mathrm{ml}$ of water, and the milled $T$. catappa leaves were added into the mixture at different concentrations. i.e. $2 \mathrm{~g}, 4 \mathrm{~g}, 6 \mathrm{~g}, 8 \mathrm{~g}$ and $10 \mathrm{~g}$. The resulting mixtures in the conical flasks were gently shaken and sterilised in an autoclave for 15 minutes at a temperature of $121^{\circ} \mathrm{C}$ and pressure of $15 \mathrm{psi}$. The medium was poured into $9 \mathrm{~cm}$ Petri-dishes. The control medium was not amended.

\subsection{Inoculation of isolates into amended medium}

A 5-mm cork borer was sterilised by dipping in methylated spirit and flamed using a spirit lamp. After that, it was used to bore the pure cultures (7-8 day old) of the isolates for discs. With the aid of a sterile inoculating needle, the discs were lifted and inoculated at the centre of the amended medium in Petridishes. Five replicate plates per isolate were inoculated and incubated for growth at room temperature $\left(30 \pm 2^{\circ} \mathrm{C}\right)$, adopting the Completely Randomized Design (CRD)

\subsection{Data Collection}

Data collections for isolate identification were done through visual observations of prepared slides over an electron microscope. Snapshots were also taken as records for pathogenicity tests on inoculated seedlings. Radial measurements of mycelial growth of isolates on both amended and unamended PDA medium were taken on 7-8 day old cultures.

\subsection{Data Analysis}


Data obtained were analysed using qualitative and quantitative statistics. The qualitative analyses were adopted to identify isolates and observations of outcomes of the pathogenicity test prescribed by Barnette and Hunter (1998). Analysis of Variance was used to test for significant differences in the radial mycelial growths on the amended PDA medium at 0.05 alpha level, and mean separations were done using the Least Square Significant Difference (LSD). The percentage growth inhibitions were also computed at all concentrations for the isolates.

See formula 1 in the supplementary files.

\subsection{Results}

It was observed that saplings infested with Hypsipylarobusta showed the disease symptoms as its boring activities made the plant susceptible to these infections. The symptom observed on the leaves was brownish spots that spread progressively on the surface of the leaves, which eventually dried up and fell off the plant. The symptom observed on the twig was a brown lesion which ultimately led to the progressive dieback of the twig (Plate 1).

Table 1: Cultural and morphological characteristics of the fungal isolates associated with the diseased leaves and twigs of Khaya grandifoliola 


\begin{tabular}{|c|c|c|c|c|}
\hline $\begin{array}{l}\text { Symptoms } \\
\text { on tissue }\end{array}$ & Isolates & Cultural characteristics & $\begin{array}{l}\text { Morphological } \\
\text { characteristics }\end{array}$ & Identification \\
\hline \multirow[t]{2}{*}{$\begin{array}{l}\text { Brown } \\
\text { spots on } \\
\text { leaves }\end{array}$} & 1 & $\begin{array}{l}\text { White cottony fast-spreading } \\
\text { fungal growth raised from } \\
\text { the medium surface, which } \\
\text { turned grey after the third } \\
\text { day with a black circular } \\
\text { pattern at the middle. At the } \\
\text { later stage, the grey culture } \\
\text { turned black. The under the } \\
\text { surface is grey with a black } \\
\text { circular pattern. }\end{array}$ & $\begin{array}{l}\text { The hyphae are septate, } \\
\text { non sporulating and } \\
\text { brown. It consists of } \\
\text { aggregated sclerotia with } \\
\text { a sterile mycelium. }\end{array}$ & $\begin{array}{l}\text { Rhizoctonia } \\
s p \text {. }\end{array}$ \\
\hline & 2 & $\begin{array}{l}\text { White cottony fast-spreading } \\
\text { fungal growth slightly raised } \\
\text { from the medium surface } \\
\text { with a delicate circular } \\
\text { pattern. At the later stage, the } \\
\text { culture turned grey with } \\
\text { orange bubble-like spores, } \\
\text { which appeared in the } \\
\text { middle. The under the } \\
\text { surface is a grey ring-like } \\
\text { pattern that has an orange } \\
\text { colouration. }\end{array}$ & $\begin{array}{l}\text { The hyphae are hyaline } \\
\text { and non-septate with a } \\
\text { mass of short, one-celled, } \\
\text { ovoid and hyaline } \\
\text { conidia. }\end{array}$ & $\begin{array}{l}\text { Colletotrichum } \\
\text { sp. }\end{array}$ \\
\hline \multirow[t]{2}{*}{$\begin{array}{l}\text { Brown } \\
\text { lesions on } \\
\text { the twig }\end{array}$} & 3 & $\begin{array}{l}\text { White slow-growing fungal } \\
\text { growth with a flat, circular } \\
\text { and ring-like pattern. The } \\
\text { under the surface is creamy } \\
\text { yellow. }\end{array}$ & & Unidentified \\
\hline & 4 & $\begin{array}{l}\text { White cottony fast-growing } \\
\text { fungal growth, which turned } \\
\text { pinkish with a delicate ring- } \\
\text { like pattern at the middle. It is } \\
\text { slightly raised from the } \\
\text { medium surface, and it } \\
\text { turned brown at the later } \\
\text { stage. The under the surface } \\
\text { is light brown. }\end{array}$ & $\begin{array}{l}\text { The hyphae are septate, } \\
\text { with slender and simple } \\
\text { conidiophores bearing } \\
\text { hyaline conidia, which } \\
\text { are slightly curved, } \\
\text { elliptical, and several } \\
\text { celled, i.e. one, two or } \\
\text { three celled. The conidia } \\
\text { are principal of two kinds } \\
\text { which are macroconidia } \\
\text { and microconidia. }\end{array}$ & Fusarium sp. \\
\hline
\end{tabular}

Results from pathogenicity test showed that Rhizoctonia $s p$. was the causal organism of the leaf blight, and it took 2(two) days for the symptom to appear on the leaves with a progressive spread of brown spots on the surface of the leaves (Plate 4). Colletotrichum sp did not give a positive pathogenicity result. However, the test showed that the Fusarium $s p$ was the causal organism for the twig dieback (Plate 5). It took 3days for the symptoms to appear. Isolate 3(whitish unidentified growth) did not give a positive pathogenicity result. 
Table 2: Radial growth (cm) of Fusarium sp. on amended PDA medium with Terminaliacatappa senescent leaves after 8 days.

\begin{tabular}{|lllllllll}
\hline $\begin{array}{l}\text { Concentration } \\
(\mathbf{g} / \text { lit) }\end{array}$ & $\begin{array}{l}\text { Radial growth } \\
(\mathbf{c m})\end{array}$ & Means & $\begin{array}{l}\text { Percentage } \\
\text { inhibition (\%) }\end{array}$ & & & & \\
\hline $0.0($ control) & 4.0 & 4.3 & 4.2 & 4.1 & 3.9 & $4.10^{\mathrm{a}}$ & 0.0 \\
\hline 2.0 & 3.0 & 2.5 & 2.6 & 2.7. & 2.9 & $2.74^{\mathrm{c}}$ & 33.2 \\
\hline 4.0 & 2.3 & 2.0 & 2.1 & 2.0 & 1.9 & $2.06^{\mathrm{d}}$ & 49.8 \\
\hline 6.0 & 3.5 & 3.0 & 3.4 & 3.6 & 3.2 & $3.34^{\mathrm{b}}$ & 18.5 \\
\hline 8.0 & 3.5 & 3.4 & 4.0 & 3.5 & 3.6 & $3.60^{\mathrm{b}}$ & 12.2 \\
\hline 10.0 & 3.7 & 4.1 & 4.0 & 3.6 & 4.2 & $3.92^{\mathrm{a}}$ & 4.4 \\
\hline
\end{tabular}

Means with the same alphabet are not statistically different at $5 \%$ level of significance.

Table 3: Radial growth (cm) of Rhizoctonia sp. on amended PDA medium with Terminaliacatappa senescent leaves after 8 days.

\begin{tabular}{|c|c|c|c|}
\hline Concentration (g/lit) & Radial growth (cm) & Means & Percentage inhibition (\%) \\
\hline 0.0 (control) & $\begin{array}{lllll}4.5 & 4.0 & 4.0 & 4.3 & 4.1\end{array}$ & $4.18^{\mathrm{a}}$ & 0.00 \\
\hline 2.0 & $\begin{array}{lllll}4.0 & 4.2 & 4.1 & 4.3 & 4.1\end{array}$ & $4.14^{\mathrm{a}}$ & 0.96 \\
\hline 4.0 & $\begin{array}{lllll}3.8 & 3.9 & 4.0 & 3.6 & 4.1\end{array}$ & $3.88^{\mathrm{b}}$ & 7.17 \\
\hline 6.0 & $\begin{array}{lllll}4.0 & 4.3 & 4.1 & 3.9 & 3.8\end{array}$ & $4.02^{\mathrm{a}}$ & 3.83 \\
\hline 8.0 & $\begin{array}{lllll}4.2 & 4.0 & 4.1 & 4.3 & 4.2\end{array}$ & $4.16^{\mathrm{a}}$ & 0.48 \\
\hline 10.0 & $\begin{array}{lllll}4.2 & 4.3 & 4.0 & 4.1 & 4.3\end{array}$ & $4.18^{a}$ & 0.00 \\
\hline
\end{tabular}

Means with the same alphabet are not statistically different at $5 \%$ level of significance.

The inhibitory effect of the senescent leaves of Terminalia catappa on the mycelial growth of Fusarium $s p$. and Rhizoctona sp. showed significant differences at $5 \%$ level of significance dosages on the development of the isolates. The radial growth of both isolates were inhibited more at $4 \mathrm{~g}$ dosage with inhibitory percentages of 49.8 and 7.17 (Tables 2 and 3, Plates 6 and 7). Thus, it can be inferred that Terminalia catappa senescent leaves can be used at a low concentration to inhibit the mycelial growth of Fusarium sp. and Rhizoctonia sp. causing twig dieback and leaf blight, respectively on Khayagrandifoliola. However, at higher concentrations, i.e dosage $6 \mathrm{~g}, 8 \mathrm{~g}$, and $10 \mathrm{~g}$ the luxuriant growth of 
the pathogens was enhanced. Therefore $T$. catappa senescent leaves can also be used at high concentrations to enhance the growth of the pathogens if the need arises.

\subsection{Discussion}

According to Boyd et al (2013), disease infection is often associated with insect pest infestations on the tree, majorly because pest creates favourable conditions for pathogens to breed. This corroborates the findings of this study. From the isolates obtained from infested leaves and twigs of Khaya grandifoliola, three pathogens, Rhizoctonia sp,Colletotrichum sp, and Fusarium sp. were identified; pathogenicity test further proved their responsibility in causing leaf blight and twig dieback on the tree species. From this study, Rhizoctonia $s p$ gave a positive pathogenicity result on the leaflet, while Fusarium $s p$ gave a positive pathogenicity result on the twigs. These symptoms observed from the pathogenicity test were consistent with Apetorgbor et al. (2003) on Ceiba pentandra. They kept that plantation of the tree species raised with nursed seedlings experienced leaf blight and twig dieback prompting unappreciable growths. They further isolate Colletotrichum capsici from the infested leaves, Fusarium solani and Lasiodiplodia theobromae on the stem diebacks. The inability of Colletotrichum sp and isolate 3 to show positive results on Pathogenicity implies that they were just associated organisms, a similar observation made on Tectona grandis by Balasundaran (2002) where Colletotrichum gloeosporioides was identified as an associated pathogen for leaf blight.

Insect pest infestation on trees induces stresses that metamorphose to poor tree growth or the eventual death of the attacked tree species (Jenoh et al., 2019). The findings of this study agree with this assertion as the inoculated Khaya grandifoliala seedlings exhibit stunted growth compared to the control and that eventually led to their death.

Several plant species have been reported to possess natural substances that are toxic to several plant fungi (Goussous et al., 2010). Thus, in testing for the inhibitory effect of Terminaliacatappa on the mycelial growth of Fusarium sp. (causal organism for twig dieback) and Rhizoctonia sp. (causal organism for twig dieback); results showed that lower concentrations of the senescent leaves (i.e. $4.0 \mathrm{~g}$ ) had a positive inhibitory effect on the pathogens. This agrees with Bashar and Chakma (2014), who reported that the inhibitory effect of plant extracts might be attributed to the presence of antifungal/antimicrobial compounds and differences in percentage inhibition might be due to the differences in nature, quality and quantity of the inhibitory substances present in the botanicals. The luxuriant growth of the pathogens was enhanced at higher concentrations. This agrees with that of Osasere (2016), who stated that the senescent leaves of Terminalia catappa had no inhibitory effect on the mycelial growth of Torulasp., but relatively supported its luxuriant growth.Awurum and Ogbonna (2013) also reported that extracts from Dennetta tripetala and Spondias mombin combated Choanephora cucubiterium, which induced wet rot amaranthus vegetable. Some tropical species like Carica papaya and Piper guineense have also strongly retarded the germination of spores of Colletotrichum destructivum (Enyiukwu and Awurum, 2011). 
Therefore, the senescent leaves of Terminalia catappa can be used at a low concentration to inhibit the mycelial growth of Fusarium sp. (causing twig dieback) and Rhizoctonia sp. (causing Leaf blight) on the saplings of Khaya grandifoliola. It can also be inferred that at higher concentrations, the senescent leaves of $T$. catappa support the luxuriant growth of the pathogens, which can be put to use if the need arises.

\subsection{Conclusion}

From the pathogenicity tests carried out on the leaf blight and stem dieback of Khayagrandifoliola saplings, it can be concluded that Rhizoctonia sp. is responsible for the leaf blight. In contrast, Fusarium $s p$. was the causal organism for the stem die back on saplings and seedlings of Khaya grandifoliola. Based on the results obtained from the inhibitory test studies, it can be inferred that the senescent leaves of Terminalia catappa can be used as an inhibitory effect on the mycelial growth of Fusarium $s p$. and Rhizoctonia sp. on the twig and leaves of Khaya grandifoliola.

\subsection{Recommendations}

It is recommended that low concentrated leaf extracts of $T$. cattappa be used for pest control in the nursery and plantations of Khaya grandifoliola. Also, more research should be done on how to effectively control and prevent the development of these fungi, causing leaf blight and stem dieback.

\section{Declarations}

\section{ETHICAL STATEMENTS AND DECLARATION}

This research work is an undergraduate Thesis of the first author (Asuelimen, E. G) which was approved of the research committee of the University of Benin, Nigeria before it was carried out. The process was monitored by a Professor of Forest Pathology in the institution (Prof. Ikhatua, M. I). There is no identified conflict of Interest and the consent of all the authors were sought before submitting this manuscripts for publication.

\section{References}

Abbiw, D. (1990). Useful plants of Ghana: West African uses of wild and cultivated plants. 337pp.

Apetorgbor M.M., Mancini F., Turco E., Cobbinah J.R., and Ragazzi, A. (2003). The involvement of Fungal pathogens in Dieback Decline of Milicia excelsa saplings in plantations. Journal of Plant Diseases and Protection. 108(6): 568-577.

Awurum A.N., and Ogbonna M.J, (2013). Field trial on the efficacy of some plants extracts on wet rot of Amaranthus cruenties L. induced by Choanephora cucurbiterium. Continental J. Agron. 7(1):10-17.

Balasundran M. (2002). Diseases of Tropical Trees. Kerala Forest Research Institute Peechi,India. 18pp. 
Barnett, A.L and Hunter B.B (1998). Illustration genera of imperfect fungi $4^{\text {th }}$ edition. Aps press. St Paul $241 \mathrm{pp}$.

Bashar, M. A and Chakma M. (2014). In-vitro control of Fusarium solani and F. oxysporum, the causative agent of brinjal wilt. Dhaka University Journal of Biological Sciences, 23(1):53-60

Boyd, I. L., Freer-Smith, P. H. , Gilligan, C. A., Godfray H. C. J. (2013). The Consequence of Tree Pests and Diseases for Ecosystem Services. Science. 342. http://dx.doi.org/10.1126/science.1235773

Enyiukwu D.N. and Awurum A.N, (2011). Effects of Phytochemicals from Carica papaya and Piper guineense seeds on the germination of spores of Colletotrichum destructivum. Continental J. Biol. Sci. 4(20): 55-59

Fern K, (2014). Khaya grandifoliola, Useful tropical plants database. 2pp.

Food and Agriculture Organization (2005) State of the World's Forests. FAO, United Nation, Rome, 153 pp Goussous S., Abu-El-Samen F.M, Tahhan R.A. (2010). Antifungal activity of several medicinal plants extracts against early blight pathogen. Alternaria solani. Phytopathol. Plant Prot. 43:1746-1758

Griffiths, M. W. (2001). The Biology and Ecology of Hypsipyla Shoot Borers. In R. B. Floyd, \& C. Hauxwell (Eds.), Hypsipyla Shoot Borers in Meliaceae: Proceedings of an International Workshop (pp. 74-80). Canberra: Australian Centre for International Agricultural Research (ACIAR).

Hauxwell, C., Mayhew, J., \& Newton, A. (2001). Silvicultural Management of Hypsipyla. In R. B. Floyd, \& C. Hauxwell (Eds.), Hypsipyla Shoot Borers in Meliaceae (pp. 151-163). Canberra: ACIAR.

IUCN (2006). IUCN Red List of Threatened Species. IUCN, Gland, Switzerland.

Jenoh E M, de Villiers E P, de Villiers SM, Okoth S, Jefwa J, Kioko E, et al. (2019) Infestation mechanisms of two wood borer species in the mangrove Sonneratia alba J. Smith in Kenya and co-occurring endophytic fungi. PLOS ONE 14(10):1-20

Lemmens, R. M. H. J. (2008). In: Loupe, D., Oteng-Amoako, A. A. \&Brink, M. (Eds).Plant Resources of Tropical Africa 7(1). Timbers 1 PROTA Foundation, Wageningen, Netherlands/ Backhuys Publishers, Leiden, Netherlands/CTA, Wageningen, Netherlands. pp. 333-338

Nakatani M., Samir A.M., Abdelgaleil, Hiroaki O., Tetsuo I., and Matsumi D. (2004). Antifungal limonoids from the fruits of khaya senegalensis. Journal ofMedicinal Plant Research. 75(6):566-72.

Odugbemi, T. O., Odunayo, K., Akinsulire, E. A. and Peter, O. F. (2007). Medicinal plants useful for malaria therapy in Okeigbo, Ondo State and Southwestern Nigeria. African Journal of Traditional Complimentary Alternative Medicine 4(2), 191-198. 
Olowokudejo, J. D., Kadiri, A. B. and Travih, V. A. (2008). An ethnobotanical survey of herbal markets and medicinal plants in Lagos State of Nigeria. Ethnobotanical leaflets 12, 851-865.

Opoku, E. M. Opuni-Frimpong, E. and Adomako, A. A. (2016). The effects of rooting media on vegetative propagation of two mahogany species (Khaya ivorensis and Khaya grandifoliola). Towards sustainable indigenous Mahogany production in Ghana: Phase II, refining the silviculture "tool kit" and practical training for industrial-foresters and community farmers. ITTO Technical Report, 2016. Pp 13

Opuni-Frimpong E., Karnosky D.F, Storer A.J, and Cobbinah J.R (2008). The effect of mixed-species stands on Hypsipyla attack on mahogany trees in the moist semi-deciduous forest of Ghana: The International Forestry Review. 7:57.

Opuni-Frimpong, E., Karnosky, D. F., Storer, A. J., \& Cobbinah, J. R. (2005). The Effect of Mixed Species Stands on Hy-psipyla Attack on Mahogany Trees in the Moist Semi-Deciduous Forest of Ghana. The International Forestry Review, 7, 57

Opuni-Frimpong, E., Karnosky, D. F., Storer, A.J., Abeney, E. A., \& Cobbinah, J. R. (2008a). Relative Susceptibility of Four Species of African Mahogany to the Shoot Borer Hypsipyla robusta (Lepidoptera: Pyralidae) in the Moist Semideciduous Forest of Ghana. Forest Ecology and Management. Special Issue; Sustainable Management of High Value Timber Species of the Meliaceae, 255, 313-319.

Opuni-Frimpong, E., Nyarko-Duah, N. Y., Belford, E. J. D., \& Storer, A. J. (2014). Silvicultural Systems for Restoration of Mahogany in Degraded Landscapes in Africa: Influence of Mixed Rainforest Plantation on Growth and Pest Damage. Open Journal of Forestry, 4, 414-425

Opuni-Frimpong, E., Nyarko-Duah, N. Y., Belford, J. D. E. and Storer, J. A. (2014). Silvicultural systems for restoration of mahogany in degraded landscapes in Africa: influence of mixed rainforest plantation on growth and pest damage. Open Journal of Forestry, http://dx.doi.org/ 10.4236/ojf.2014.44046

Osasere E.N, (2016). Fungal spoilage of Gmelina arborea ROXB. Fruits and seeds. A project work of the Department of Forest Resources and Wildlife Management, Faculty of Agriculture, University of Benin, Benin City. 33pp.

Oyewale O. B., Kayode, O. A., and Oluyemisi, O . A. (2011). Antimicrobial, free radical scavenging and cytotoxic activities of Khaya grandifoliola C.DC extracts. Malaysian Journal of Microbiology, 12(3) 233238

\section{Figures}




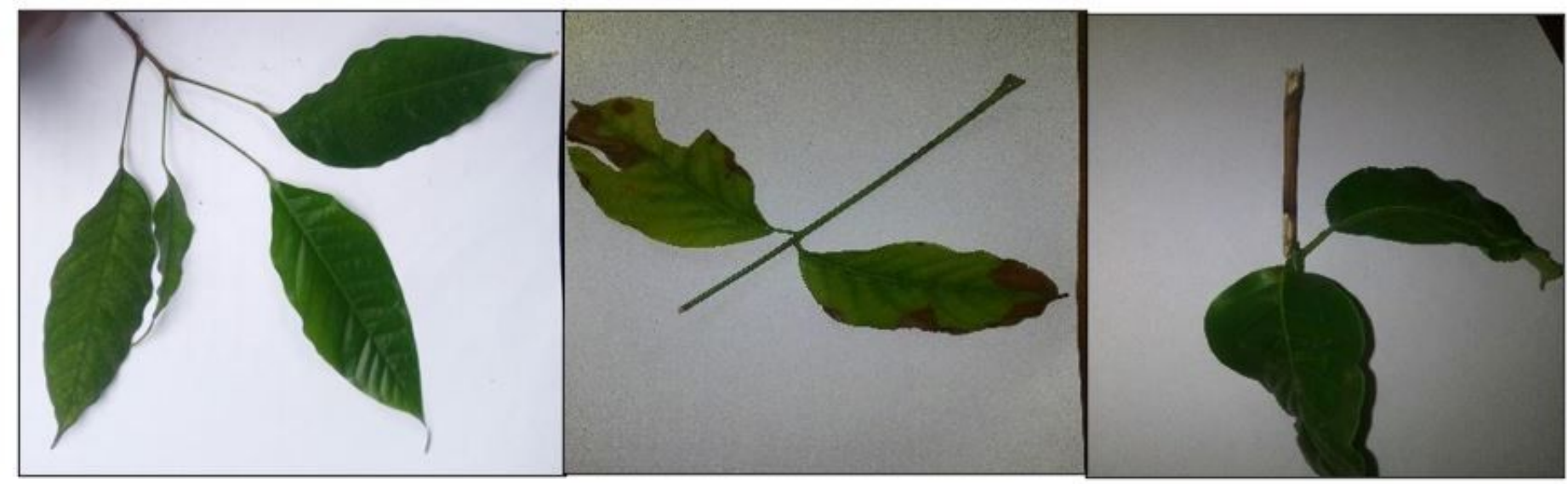

\section{Figure 1}

Light micrograph showing healthy leaflets (left), diseased leaf (middle) showing the progressive blight of leaflets, and diseased twig (right) showing the progressive dieback. Four fungal isolates (two each) were found on the leaves and stem. The fungal isolates associated with the leaf blight were Rhizoctonia sp. and Colletotrichum sp. (Plate 2). In contrast, the fungal isolates associated with the stem dieback were Fusarium sp and an unidentified isolate.

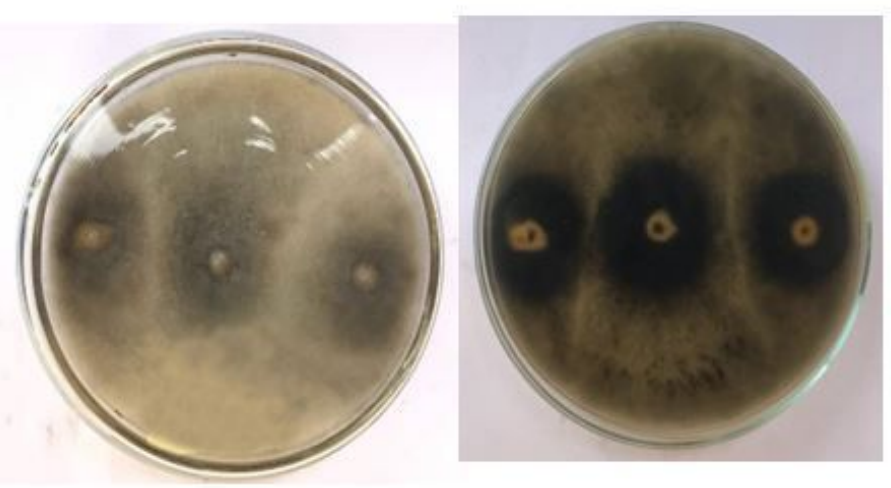

(a)

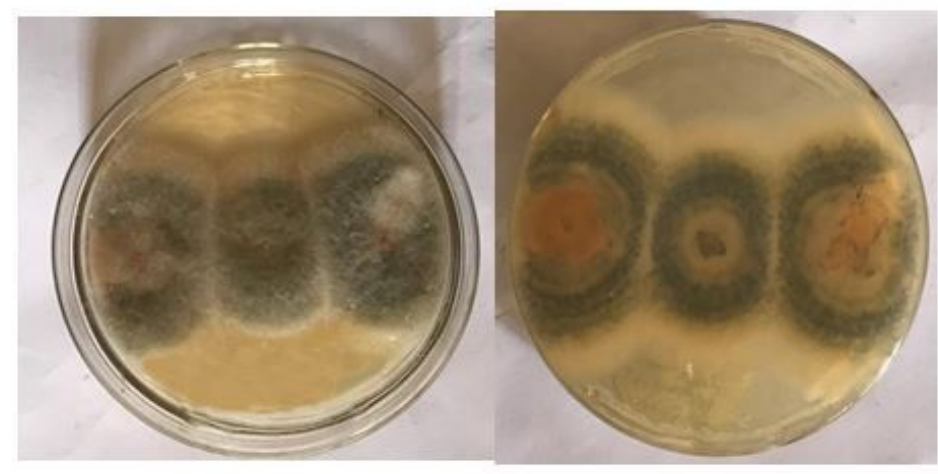

(b)

\section{Figure 2}

Light micrograph of the cultural characteristics of Rhizoctonia sp. (a) and Colletotrichum sp. (b), which were isolated from the blight of leaves. Upper surfaces (left)andlower surfaces (right). 


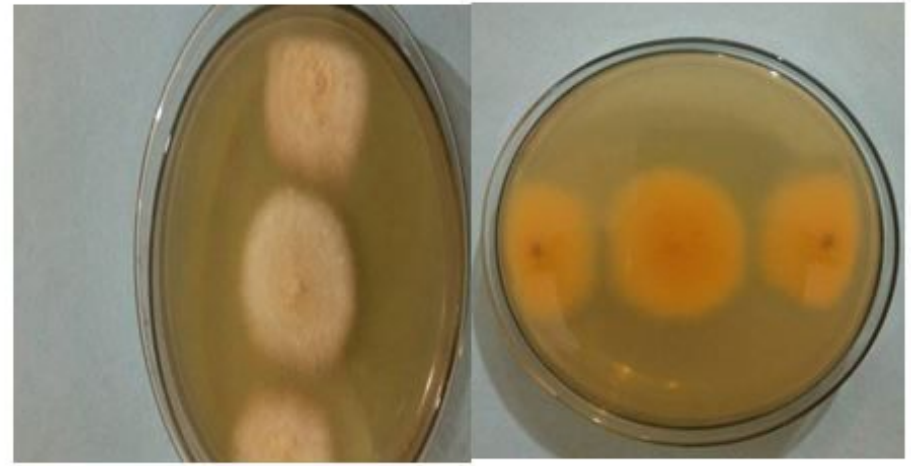

(a)

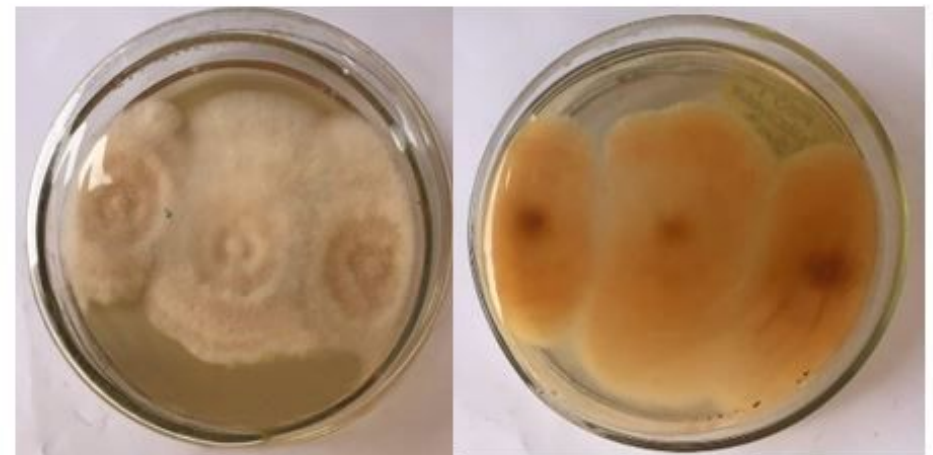

(b)

\section{Figure 3}

Light micrograph of the cultural characteristics of isolate 1(a) and Fusarium sp. (b) isolated from the twig dieback. Upper surfaces (left) and under surfaces (right).
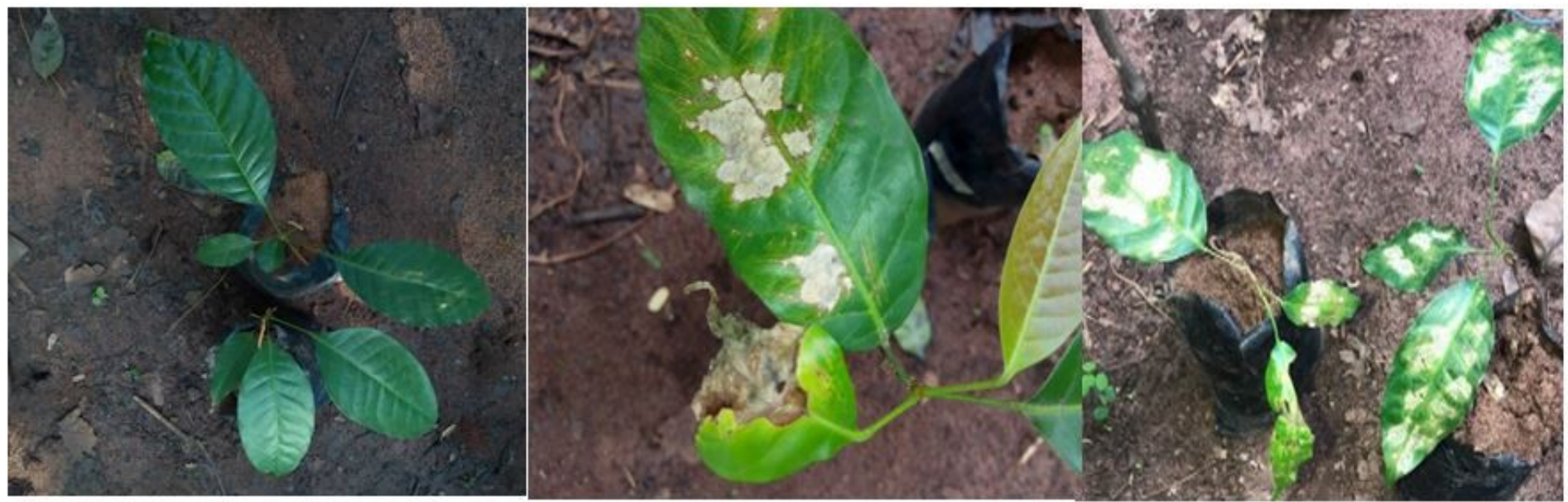

\section{Figure 4}

Light micrograph of inoculated leaves at pathogenicity test. From left to right are control seedling, inoculated seedlings with Rhizoctonia sp. and Colletotrichum sp. 


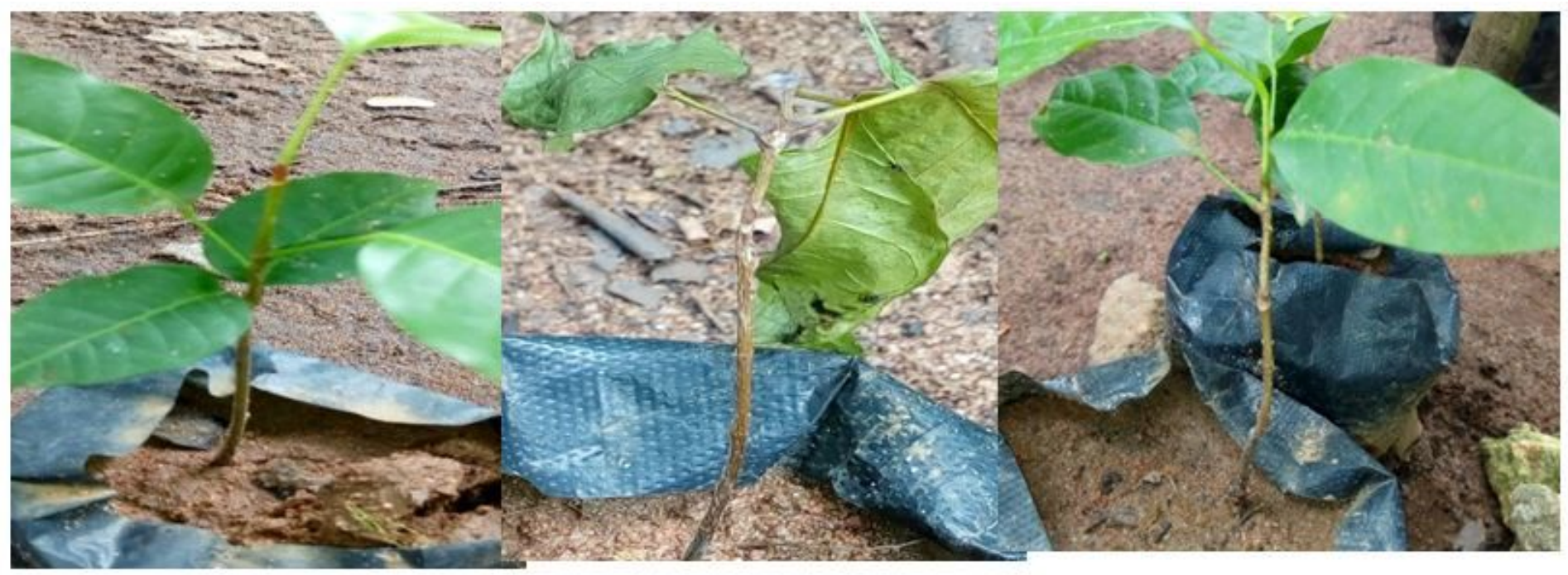

\section{Figure 5}

Light micrograph of inoculated twig at pathogenicity test. From left to right are control seedling inoculated seedlings with Fusarium sp. and isolate 4.

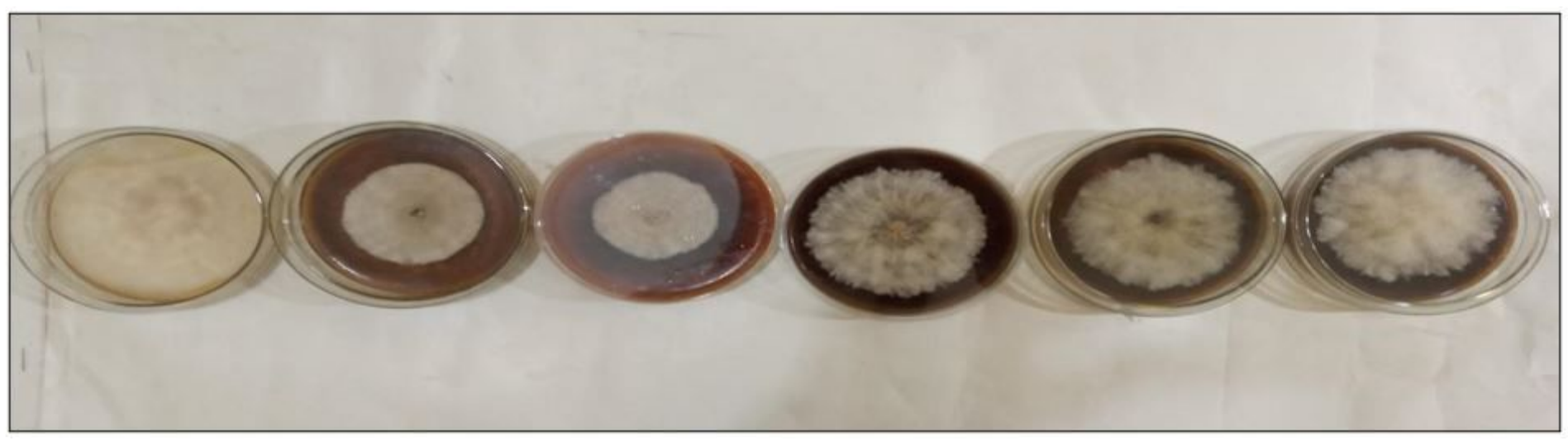

\section{Figure 6}

Light micrograph of 7-8 day old cultures of Fusarium sp. on PDA amended medium with different concentrations of the senescent leaves of Terminalia catappa. From left to right controls $(0.0 \mathrm{~g}), 2 \mathrm{~g}, 4 \mathrm{~g}$, $6 \mathrm{~g}, 8 \mathrm{~g}$, and $10 \mathrm{~g}$, respectively.

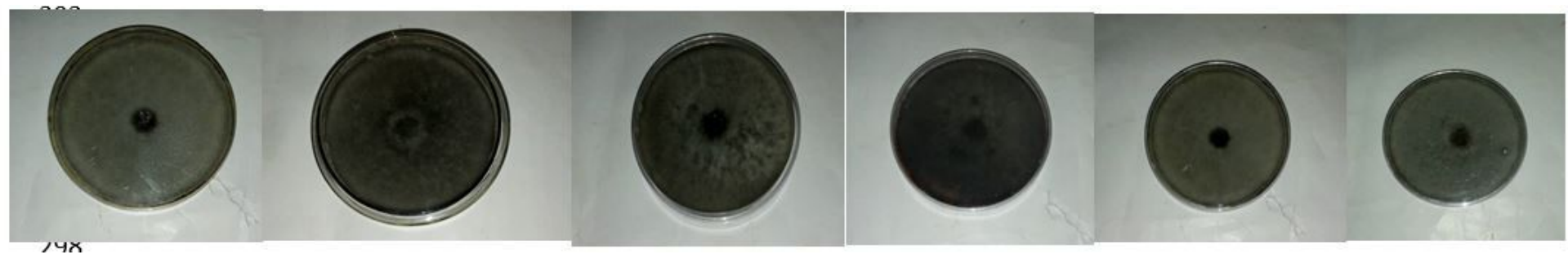

\section{Figure 7}

Light micrograph of 7-8 day old cultures of Rhizoctonia sp. on PDA amended medium with different concentrations of the senescent leaves of Terminalia catappa .from left to right are control $(0.0 \mathrm{~g}), 2 \mathrm{~g}, 4 \mathrm{~g}$, 
$6 \mathrm{~g}, 8 \mathrm{~g}$, and $10 \mathrm{~g}$ respectively.

Page 16/16 